\title{
"Blessed are the pure in heart, for they shall see God" (Matt 5:8) as Interpreted by the Church Fathers (4th-5th cent.)
}

\author{
PAWE $\leftarrow$ WYGRALAK
}

Adam Mickiewicz University in Poznań

pawelwyg@amu.edu.pl, ORCID: 0000-0001-7790-7864

\begin{abstract}
The article presents the statements of selected Church Fathers (4th-5th centuries) concerning the Beatitude "Blessed are the pure in heart, for they will see God" (Matt 5:8), spoken by Jesus in the Sermon on the Mount. They emphasise that during the earthly life man can only see the reflection of God if his heart is pure. Since man was created in the image and likeness of God, he carries this image in his heart, but this image was polluted by sin. Therefore, one should purify the heart by renouncing sins and developing virtues. The most important comments on this issue were expressed by St Gregory of Nyssa and St Augustine.
\end{abstract}

Keywords: seeing God, pure heart, Beatitude, Fathers of the Church

The Beatitude "Blessed are the pure in heart, for they shall see God" (Matt 5:8), spoken by Christ in the Sermon on the Mount, contains a challenge and promise that are important to Christians. For everyone who deeply lives their faith has a desire to see God, but being aware of the limitations of human cognition, he asks whether it is at all possible. There are also other questions about understanding the attitude of "pure heart" and how to purify the heart so that Christ's promise may be fulfilled. These questions and doubts that may arise were dealt with by the Fathers of the Church, among whom St Gregory of Nyssa and St Augustine gave the broadest and deepest spiritual comments. The subject of the Beatitudes was considered to a lesser extent by St John Chrysostom, St Jerome, St Chromatius of Aquileia, St Hilary of Poitiers, St Leo the Great, Apollinaris of Laodicea or the anonymous author of the commentary on the Gospel of Saint Matthew. This paper, based primarily on the statements of the aforementioned ancient exegetes as well as on earlier studies - following the line of thought of St Gregory of Nyssa - is an attempt to present the Fathers' thoughts on the possibility of seeing God, their understanding of the concept of "pure heart" and to show how Christians can achieve this purity. 


\section{Seeing God}

From among the aforesaid authors it was St Gregory of Nyssa who devoted much space to the possibility of seeing God on earth. He realised that he was undertaking a difficult task because many biblical passages reveal that it is impossible to see God. Both St John and St Paul, and Moses before them, definitely stated that "No one has ever seen God" (John 1:18), "whom no human being has seen or is able to see" (1 Tim 6:16) and "for no human being can see me and survive" (Exod 33:20). ${ }^{1}$ Contrary to such unequivocal statements uttered by important biblical figures, the Bishop of Nyssa is convinced that seeing God is possible for at least four reasons, though he did not justify all of them in his work. Firstly, we are able to see God since God is life, so the inability to see God deprives us of life; secondly, if it were not so, what would human hope be based on? In Gregory's opinion, it is precisely the words of this Beatitude that are God's hand stretched out to all humans to strengthen them, just as Jesus gave his hand to Peter who was drowning and set him on the stable water; thirdly, we can describe what seeing God is, but do we need knowledge that cannot be put into practice? And fourthly, it is impossible for God to call man to something that is beyond his nature. ${ }^{2}$ If these arguments were not enough, Gregory is sure that although both the apostles John and Paul as well as Moses thought that man cannot see God, they themselves obtained this grace. ${ }^{3}$ Therefore, it is true that man cannot know God and his nature through rational cognition. Yet, it is also true that this kind of understanding is possible. Gregory assures us: "Since the one who transcends all nature is by nature such, it is by some other principle that the Invisible and Incomprehensible is both seen and comprehended. There are many kinds of such understanding." ${ }^{3}$ One of them is the possibility of getting to know God by analogy to the world created by him. ${ }^{5}$ In order to illustrate his thesis, the Bishop of Nyssa uses an example taken from real life: works made by artificers or craftsmen show their proficient skills. However, we cannot say anything about the reality of the makers themselves. Similarly, looking at the order in creation, we can tell a lot about the wisdom of the Creator, but unfortunately nothing about his character. Thus, we can speak of God's goodness, power and immutability. All this makes us recognise that we know God, although in fact we comprehend the properties he possesses, and not his nature. ${ }^{6}$

The considerations of Apollinaris of Laodicea are similar: "God is seen in the same way that in objects made by human beings, the maker of a given work is, after a certain manner, seen by the intellect. But what is seen is not the nature of

\footnotetext{
Cf. Gregorius Nyssenus, De beatudinibus, oratio VI, 137 (GNO 7/2, 137).

Cf. Gregorius Nyssenus, De beatudinibus, oratio VI (GNO 7/2, 138-139).

Cf. Gregorius Nyssenus, De beatudinibus, oratio VI (GNO 7/2, 139-140).

Gregorius Nyssenus, De beatudinibus, oratio VI (GNO 7/2, 140-141; VCSup 52, 68).

Cf. Tyburowski, „Człowiek jako obraz, 316.

Cf. Gregorius Nyssenus, De beatudinibus, oratio VI (GNO 7/2, 141).
} 
the artificer but only his or her artistic skill. So also, whoever sees God by looking at the creation gains an impression not of the essence but of the wisdom of the One who has made all things." ${ }^{\prime}$ Consequently, we can say that God was made visible in his works although his nature remains unknowable. This thought is demonstrated by St Paul in the Letter to the Romans: "ever since the creation of the world, the invisible existence of God and his everlasting power have been clearly seen by the mind's understanding of created things" (Rom 1:20).

Gregory of Nyssa goes further in his considerations. According to him, seeing God is possible only when a human being possesses him in himself: "the Lord does not say that knowing something about God is blessed, but to possess God in oneself." ${ }^{8}$ Here he uses the words of Christ who assured his listeners that the kingdom of God is in their midst (cf. Luke 17:21). Man can see the image of God's nature in himself as long as he purifies his heart of sinful inclinations. For God has imprinted on man the image of his own nature "as though stamping wax with the shape of a design." Then he "perceives in his own beauty the reflexion of the divine nature." 10 Thus knowing God would mean knowing his reflexion in man's inner self, i.e. his heart that is free of sin. This idea appears in Gregory's commentary on the sixth Beatitude $^{11}$ and is developed in his other works, including his earlier work On Virginity or the treatise On the Making of Man, in which he comments on Gen 1:26: "Let us make man in our own image, in the likeness of ourselves." The truth about man being created in the image and likeness of God is also Gregory's starting point to consider the possibility of knowing God. Man, being God's unique creature, bears his image in himself. ${ }^{12}$ And as the nature of God is perfect so is his image in man. Here we can compare God to the sun, and man to a mirror that reflects the sun. ${ }^{13}$ Thus, getting to know one's self, cleansed of the stain of sin, leads to seeing God in the inner man. ${ }^{14}$

A similar conviction about the possibility of seeing God within oneself also appears in the commentary of St Augustine to Psalm 67(66):4. The Bishop of Hippo first uses the second verse of the commented Psalm: "May God show kindness and bless us, and make his face shine on us" and also the text of the Beatitude in question, explaining how we should understand the prayer "may he make his face shine on us."

7 Appolinarius Laodicenus, „Fragmenta in Matthaeum 13, 1-13” (TUGAL 61, 5; ACCS.NT 1a, 94).

8 Gregorius Nyssenus, De beatudinibus, oratio VI (GNO 7/2, 142; VCSup 52, 69-70); cf. Tyburowski, „Człowiek jako obraz," 316.

9 Gregorius Nyssenus, De beatudinibus, oratio VI, 143 (GNO 7/2, 143; VCSup 52, 70).

10 Gregorius Nyssenus, De beatudinibus, oratio VI, 142 (GNO 7/2, 142; VCSup 52, 70). Here Gregory refers to the view proclaimed by Plotinus in The Enneads I, 9, 6; III, 8, 11; VI, 9, 11 .

11 This work originated most probably around $378 \mathrm{AD}$. According to Jean Daniélou ("Chronologie des oeuvres," 159-162), it is one of the earliest writings of Gregory of Nyssa. Cf. Czyżewski, „Błogosławieni,” 233.

12 Cf. Mateo-Seco, „Obrazy Obrazu," 376; Uthemann, “Gregor von Nyssa," 199.

13 Cf. Ladaría, „Człowiek stworzony na obraz Boga,” 96-97; Tyburowski, „Człowiek jako obraz, 316. This conception is rooted in Greek philosophy, e.g. in Plato's thought. Cf. Plato, Timaios 29B-C; Przyszychowska, "Wstęp," 18-19.

14 Cf. Uthemann, "Gregor von Nyssa," 200-201. 
It is a request "so that what was hidden from us may be seen openly. Let what was light already, but concealed from our sight, be revealed for us; let it be lit up for us. The other way of understanding the verse is to take it like this: 'Illumine your own image in us.' The psalms would then be praying, 'Bring out the light of your face in us. You have stamped your features upon us, you have made us in your own image and likeness; you have made us your coin." ${ }^{15}$ Referring to the truth that man was made in the image and likeness of God, Augustine clearly states that we carry God's image and likeness in ourselves in the same way as the image on the coin relates to its archetype, i.e. to the face of the emperor. It is important that there is not only a similarity between the image and pattern, but that the likeness comes directly from the pattern. ${ }^{16}$ So it is possible to see God in his reflection, which man received in the act of creation. Unfortunately, it has been blurred by sin. Therefore, in order for man to know God in his reflection, God's purifying grace is needed, which is the aim of the request: "lighten Your countenance upon us." In his commentary on the Sermon on the Mount, the Bishop of Hippo says that the special gift of pure eyes can be defined as the ability to see God (facultas videndi Deum). ${ }^{17}$ Thanks to this ability, the faithful receive the gift of understanding eternal truths. In his work On the Trinity, Augustine speaks about looking at God through the eyes of the spirit. For God is not a body, and so he cannot be seen with carnal eyes. ${ }^{18} \mathrm{He}$ even states that those who think that seeing God is possible with outward eyes are foolish. ${ }^{19}$

The anonymous author of the commentary on the Gospel of Saint Matthew, previously attributed to St John Chrysostom, ${ }^{20}$ understands the ability to see God slightly differently. In his opinion, God is justice and "justice is the likeness of God,"21 thus those who follow justice and intend to continue this way of conduct can see God. Man's participation in seeing God is connected with his participation in extraordinary spiritual goods that are listed by Gregory of Nyssa: "unending life, eternal imperishability, immortal blessedness, endless Reign, unceasing happiness, true light, spiritual and sweet speech, unapproachable glory, everlasting joy, everything good."22

15 Augustinus Hipponensis, Enarratio in Psalmum 66,4 (CCL 38, 861; Augustine of Hippo, Expositions of the Psalms, 314).

16 Cf. Augustinus Hipponensis, De Genesis ad litteram opus imperfectum 16, 57 (PL 34, 242); Krupa, Obraz Boży, 9.

17 Cf. Augustinus Hipponensis, De sermone Domini in monte I, 4.12 (PL 34, 1235).

18 Cf. Augustinus Hipponensis, De Trinitate VIII. IV.6 (PL 42, 351).

19 Cf. Augustinus Hipponensis, De sermone Domini in monte I, 2.8 (PL 34, 1232).

20 The commentary of the anonymous author of Opus imperfectum in Matthaeum was transmitted as a work of John Chrysostom. Most likely, the author is some unknown Arian priest living in the 5th century. This commentary has been studied by many authors, e.g. Simonetti, "Note sull'Opus," 117-200; Nautin, "L'Opus imperfectum," 381-408, 745-766.

21 Anonymous, Opus imperfectum in Matthaeum IX (PG 56, 682; ACCS.NT 1a, 87).

22 Gregorius Nyssenus, De beatudinibus, oratio VI, 138 (GNO 7/2, 138; VCSup 52, 67). 
Gregory Nyssen neither comments on nor describes the gifts. He did not say where he had learnt about them, either.

On the other hand, Leo the Great does not mention the possibility of seeing God in mortality. He is convinced that man will see God only when man's nature is transformed, and so in eternity. For human sight cannot see the Divinity. Referring to St Paul, the Bishop of Rome assures us that it will then be seeing not in a mirror nor in a dim reflection. Face to face each one will see that divinity" (cf. 1 Cor 13:12) ${ }^{23}$ The pure in heart will regard seeing God as a fullness of blessedness - the unspeakable joy (iucunditas). But for those that are stained by sin, it will be a punishment because it is impossible for a sinner's sight to withstand the brightness of the true light. ${ }^{24}$

In conclusion, it should also be noted that the commentaries on the sixth Beatitude by other authors of the period in question lack a broader interest in the problem of how man can see God. Neither John Chrysostom nor Jerome of Stridon or Chromatius of Aquileia in their commentaries on the Gospel according to Saint Matthew do not deal with this issue. They are more interested in questions of a moral and ascetic nature regarding the possibility and method of purifying the Christian heart so that believers can see God.

\section{Pure heart}

Only those that have a pure heart can see God. What, then, is it to have the condition of the heart pure? In Sacred Scripture, unlike today, the heart is associated not only with the sphere of emotions but it is a symbol of man's inner self. It is the place where the laws of nature are inscribed; it is the place of all thoughts and decisions; it is here that the dialogue between God and man takes place, and it is also the place where God himself acts in a mysterious way. ${ }^{25}$ The Greek term katharos - "pure," used in the Gospel of Saint Matthew, means "without any admixture, free from adhering to anything that stains or demoralises, unadulterated, without foreign elements (not melted with anything)." ${ }^{26} \mathrm{~A}$ pure heart means righteousness, the nobility of intention, goodness and a clear conscience. ${ }^{27}$

Saint Augustine urges us, in accordance with the words of encouragement found in the Book of Wisdom, to "seek him in simplicity of heart" (Wis 1:1), adding that a pure heart is a single heart (simplex cor).$^{28}$ The Bishop of Hippo holds on to this

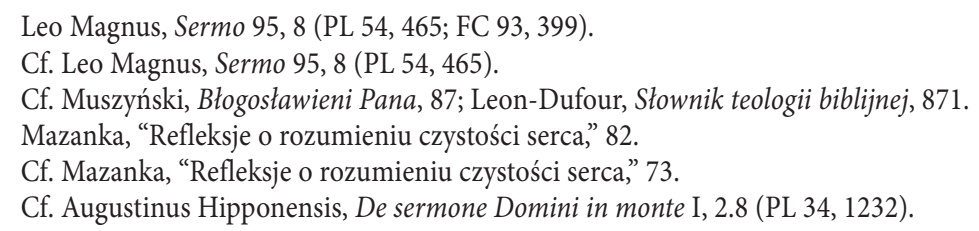


meaning teaching that the purity of the heart comes from a clear conscience and righteous deeds, and that it enables man to contemplate the highest good. ${ }^{29}$ On the other hand, John Chrysostom describes "the pure" as those who possess all the virtues, those who are not repelled by their conscience, those who live soberly. ${ }^{30}$ In turn, Chromatius of Aquileia says that the pure in heart are all those who have entrusted their lives to God and whose conscience is unblemished. ${ }^{31}$ According to Leo the Great, the faithful who strive after virtues have pure hearts, the virtues that are mentioned in Jesus' beatitudes, i.e. poverty, meekness of heart, justice and mercy. ${ }^{32}$

In his considerations on purity of heart, Gregory of Nyssa points to other criteria. According to him "Godhead is purity, absence of passion, and separation from every evil. If these are in you, God is certainly in you. When the mind in you is unmixed with any evil, free from passion, and far away from any stain, you are blessed for your sharp sightedness, for by becoming pure you have perceived what is invisible to those not purified, and, with the materialistic fog removed from eye of the soul, in the pure shining of the heart you see the blessed sight. [...] Purity, sanctification, simplicity, all such things are the luminous outpoured rays of the divine nature by which God is seen." ${ }^{33}$ A pure heart reflects God's full image that unstained man received in the act of creation. It is also worth stressing that Gregory's idea about purity of heart, which is expressed in the insensitivity to sensations, freedom from passion, coincides with the state described by Clement of Alexandria, described by the term apatheia. The Bishop of Nyssa knows Clement's work and uses it, but his deliberations go further and deeper. ${ }^{34}$ Yet, Hilary of Poitiers notes that a pure heart designates those who are "perfected in spirit and changed into immortality" (spiritu perfecti, immortalitate immutati), ${ }^{35}$ and only they can receive the gift of seeing in God what is immortal, that is to say, his Divinity.

It should be emphasised that, according to the Church Fathers, the possibility of seeing God in one's own self is achieved only by those who purify their hearts in their spirituality, which allows them to contemplate and experience mystical states. They have - as St Augustine says - the sense of seeing: the eyes of the spirit. These terms are to be understood as "pure heart." Since only the pure heart, in accordance with its biblical meaning, is an organ of perfect contemplation, making it possible to see God already here, on earth. ${ }^{36}$

29 Cf. Augustinus Hipponensis, De sermone Domini in monte I, 3.10 (PL 34,1234).

30 Cf. Johannes Chrysostomus, In Matthaeum homiliae XV, 4 (PG 57, 227).

31 Cf. Chromatius Aquileiensis, "Tractatus LXI in evangelium Matthaei XVII, 6, 4" (CCL 9A, 275).

32 Cf. Leo Magnus, Sermo 95, 8 (PL 54, 465).

33 Gregorius Nyssenus, De beatudinibus, oratio VI, 144 (GNO 7/2, 144; VCSup 52, 70-71).

34 Cf. Clemens Alexandrinus, Stromata VI, 9 (PG 9, 291-300). Špidlík - Gargano, "Duchowość Ojców," 130-132. Clement thinks that we can reach the state of seeing God face to face. See Przyszychowska, "Wstęp," 7-12.

35 Hilarius Pictaviensis, Commentarius in Matthaeum IV, 7 (SCh 254, 124; FC 125, 61).

36 Cf. Špidlík - Gargano, “Duchowość Ojców," 142. 


\section{The way to cleanse the heart}

Many questions and doubts arise in the Church Fathers' reflections on the possibility of purifying the heart and, consequently, the gift of seeing God. It is related to their awareness of how great, extraordinary and undeserved this spiritual good is. Thus Gregory of Nyssa expresses his doubts in words that show the desire to see God, and at the same time the fear that seeing God is not attainable: "Such and so great is the hopeful prospect in the promise of blessedness. When however we are warned that the way we come by this vision is to become pure in heart, at that my mind reels again: perhaps purity of heart is impossible and goes beyond our nature!" ${ }^{37}$ Saint Augustine notices that man has a desire to see God. This is the goal he is striving for. It is so sublime that when he reaches it, all other desires will be forgotten. "Indeed, what would one search for when one has God before one's eyes?" ${ }^{38}$ And Saint Jerome adds: "A pure man is conspicuous for his pure heart; the temple of God cannot be polluted." ${ }^{39}$ Hilary of Poitiers says that only those can endure for the sight of God that become capable of doing this through the brightness of the soul and purity of life. ${ }^{40}$ So one must purify the heart. ${ }^{41}$

Man's tragedy is the inability to see God in his or her own self, even though God imprinted his image in man in the act of creation. Gregory of Nyssa points out that this was caused by evil that "has made the good useless to you, hidden under curtains of shame." ${ }^{42}$ The evil, which is sin and all passions, accompanies man from the very birth. It mixed with human nature at the time of the first parents' sin. Gregory says directly about the heredity of the sinful nature: "Just as with each kind of animal the species continues along with the succession of the new generation, so that what is born is, so from man man is generated, from passionate passionate, from the sinful its like." ${ }^{33}$ Therefore, sin accompanies man throughout his life. This does not mean, however, that it would be impossible to fight sin and lead us to the final victory as shown by the examples of the holy men's lives that are described in the books of the Bible. Nevertheless, the path to the victorious gaining of virtues is narrow and difficult according to the teachings of the Lord (cf. Matt 7:13). ${ }^{44}$ In his opinion, purifying the heart from all kinds of blemish is no less difficult than ascending to heaven. Thus, he raises questions that refer to the events of the Old Testament: "What

\footnotetext{
37 Gregorius Nyssenus, De beatudinibus, oratio VI (GNO 7/2, 138; VCSup 52, 67).

38 Augustinus Hipponensis, "Sermo 53, 6" (PL 38, 366; ACCS.NT 1a, 93).

39 Hieronymus, Commentariorum in Matthaeum I, 5, 8 (SCh 242, 107; FC 117, 76). Cf. Degórski, "Beatitudini", 273.

40 Cf. Hilarius Pictaviensis, Commentarius in Matthaeum IV, 7 (SCh 254, 124).

41 Cf. Augustinus Hipponensis, Enarratio in Psalmum 26, 15 (CCL 38, 162).

42 Gregorius Nyssenus, De beatudinibus, oratio VI (GNO 7/2, 143; VCSup 52, 70).

43 Gregorius Nyssenus, De beatudinibus, oratio VI (GNO 7/2, 145; VCSup 52, 71).

44 Cf. Gregorius Nyssenus, De beatudinibus, oratio VI (GNO 7/2, 145).
} 
sort of Jacob's ladder (cf. Gen 28:12) is to be found, what sort of fiery chariot like the one which carried up the prophet Elijah to heaven (cf. 2 Kgs 2:11), by which our heart might be lifted up to the marvels above, and shake off this earthly burden? ${ }^{45}$ So, the first step to cleanse the heart is the imperative to reject evil. The teaching of the Gospel is helpful, showing that there are two kinds of evil: committed by deeds and committed by thoughts. The former was condemned already in the Old Testament. In the New Testament, Christ gave the new law, having in mind the other kind of sin. The point is to destroy the very thought that sins are allowed. It is, therefore, necessary to remove evil with our free will in order to eliminate all evil deeds. At the same time, according to the Bishop of Nyssa, Christ, in order to counteract all evil, prepared a different cure, i.e. a commandment for each kind of evil. Gregory notes that anger is the dominant human infirmity. And just as God forbade killing in the Old Testament, so Christ requires us to purify our hearts of all kinds of anger towards our neighbours (cf. Matt 5:21). Next, following the order of God's commandments, we should remove offences committed through pleasure from our lives; special attention should be given first to the sin of adultery and then to the passion of greed, which is often the cause of the sin of stealing. Along these lines, the word of God contained in the commandments can be compared to "a plough digging out the roots of sins from the bottom of our heart, by which means it is possible to be cleared of the harvest of thorns (cf. Matt 7:16-20). ${ }^{46}$ Certainly, this fight against sin refers to that known from Plotinus, ${ }^{47}$ and also used by Gregory, comparing the purification of the heart to the cleaning of iron from rust: "Just as happens in the case of iron, when it is stripped of rust by a whetstone, and what once was dull gleams of its own accord as it faces the sun and gives forth beams and shafts of light, so also the inner man, which is what the Lord calls 'the heart,' once it has wiped off the rusty filth which has spread by evil corrosion over its form, will once again recover its likeness to its archetype and be good." ${ }^{38}$ This comparison shows that fighting sin takes effort.

Similar encouragements to fight against sin as the first step on the way to purity of heart are found in St Augustine. In his considerations, he refers to the image of watching the rising sun. He suggests that no one wants to see the sunlight with rheumy eyes. You should try to keep them healthy. Only then you are able to experience true joy from the light that you can see. ${ }^{49}$

However, if conversion is to be effective, you must get to know yourself. You are to look into the mirror of your soul and see the truth about yourself in it. The reflection in the mirror of the soul shows what you are like. If you are not satisfied with

\footnotetext{
Gregorius Nyssenus, De beatudinibus, oratio VI (GNO 7/2, 144; VCSup 52, 71).

Gregorius Nyssenus, De beatudinibus, oratio VI (GNO 7/2, 147; VCSup 52, 73).

Cf. Plotyn, Enneady IV, 7, 10.

Gregorius Nyssenus, De beatudinibus, oratio VI (GNO 7/2, 143; VCSup 52, 70).

Cf. Augustinus Hipponensis, Sermo 53, 6 (PL 38, 366).
} 
yourself, you should try to change yourself. ${ }^{50}$ Augustine emphasises that even if you see the ugliness of your soul, you are already enjoying God's love. In this way, you gain another motive and strength to change yourself. For this to happen, according to the Bishop of Hippo, and also to Gregory of Nyssa, what is needed is first of all to observe the Decalogue. He guarantees that by applying the eyewash of mordant commandments ("mordax praeceptum quasi collyrium") the sinner's eyes will be cleansed..$^{51}$ The comparison of the commandments to a medication indicates their healing nature - here we see once again the convergence with Gregory's thought; and to call it "mordant" ("mordax") designates that it is a painful treatment, requiring the effort of the patient-sinner.

Also, John Chrysostom urges us to keep the commandments. By the concept of purity of heart, he understands first of all freedom from debauchery and pleasures of the flesh, which clearly refers to the necessity to obey the sixth commandment. At the same time, he notices - which distinguishes his recommendations from those made by the other Fathers - that it is necessary to follow the recommendations contained in the previous Beatitudes, i.e. to perform works of mercy, rejecting all forms of extortion and greed..$^{52}$ Chromatius of Aquileia teaches that one ought to get rid of the filth of sin and to cleanse your body. He does not clearly explain what he means by this purification. However, it can be presumed that he means sexual purity. So, like John Chrysostom, he emphasises the need to fight sins against the sixth commandment. ${ }^{53}$ In turn, Leo the Great encourages us to fight even the slightest iniquity and at the same time to try to deserve the vision of God by living in harmony with the Beatitudes. ${ }^{54}$

The Fathers of the Church, speaking about the path to purity of heart, indicate not only the need to reject sins and to fight evil, but they also encourage us to deepen our spirituality, and thus our relationship with God. Hence it is important to progress in good. According to Gregory of Nyssa, such a progress will be made easier if we compare life in good and life in evil. Living in evil is more burdensome because those who live in it must look into the face of the Adversary; they will experience darkness, death and corruption. The mere knowledge of the consequences of wrong-doing should at least cause them to fear hell. Moreover, they should be encouraged by the awareness that abiding in God means light, life and imperishability. Gregory emphasises that the knowledge of what is good and what is evil is important to man since he is empowered to choose the path of life. If he discards the mask of evil and

\footnotetext{
Cf. Augustinus Hipponensis, Enarratio in Psalmum 103, (1) 4 (CCL 38, 1476).

Cf. Augustinus Hipponensis, Enarratio in Psalmum 39, 21 (CCL 38, 441).

Cf. Johannes Chrysostomus, In Matthaeum homiliae XV, 4 (PG 57, 227).

Cf. Chromatius Aquileiensis, "Tractatus in evangelium Matthaei XVII, 6, 3-4" (CCL 9A, 274-275).

Cf. Leo Magnus, Sermo 95, 8 (PL 54, 465).
} 
puts on the divine image and becomes pure in heart, he will become blessed. Only pure conduct will fashion the divine image in man. ${ }^{55}$

On the other hand, the anonymous commentator of the Gospel of Saint Matthew emphasises that only those who neither do anything wrong nor intend to do it, and those "who also always do and intend everything good"56 have pure hearts. For Augustine, faith and love are important on the way to purity of heart. He mentions the two virtues many times. According to him, it is through faith that the heart is purified ${ }^{57}$ However, relating this conviction to the sixth Beatitude, he does not indicate how we can deepen and strengthen faith. Significantly, he always connects faith with the attitude of love. Yet, in the commentary to Psalm 83, he draws our attention to the necessity of shaping the virtues that are given through God's grace. All of them are directed to one virtue, i.e. to contemplating God. The Bishop of Hippo concludes: "When all is finished, that mortality makes necessary, He shall appear to the pure in heart, as He is, "God with God," The Word with the Father." ${ }^{8}$ Man must, therefore, come to a state in which the things of this world will recede into the background; they will be meaningless in relation to abiding in God.

A completely isolated conclusion among the ancient exegetes under discussion is made by the anonymous author. He believes that the clarity of seeing God in one's heart depends on the degree of man's breaking with evil. Thus man can see him "either dimly or clearly, or slightly or to a greater degree, or partly or completely, or now and then or always, or in accordance with human possibility." ${ }^{\prime 59}$ Nonetheless, it is certain that people will see God not as in a mirror, but face to face only in the world to come as St Paul tries to persuade the community in Corinth (cf. 1 Cor 13:12). ${ }^{60}$

\section{Conclusion}

The broadest and most theologically developed commentaries on the sixth Beatitude were provided by St Gregory of Nyssa and St Augustine. Although their comments are similar in many respects, it is difficult to talk about their mutual dependence. Both of them certainly drew from the thoughts of Plato and Plotinus.

\footnotetext{
55 Cf. Gregorius Nyssenus, De beatudinibus, oratio VI (GNO 7/2, 147-148).

56 Anonymous, Opus imperfectum in Matthaeum IX (PG 56, 682; ACCS.NT 1a, 87).

57 Cf. Augustinus Hipponensis, Enarratio in Psalmum 130, 8 (CCL 38,441); idem, De Trinitate I, XIII, 31 (PL 42, 844).

58 Augustinus Hipponensis, Enarratio in Psalmum 83, 11 (CCL 38, 1158; Augustine of Hippo, Expositions on the Psalms, 695).

59 Anonymous, Opus imperfectum in Matthaeum IX (PG 56, 682; ACCS.NT 1a, 87).

60 Anonymous, Opus imperfectum in Matthaeum IX (PG 56, 682; ACCS.NT 1a, 87).
} 
It should be noted that, in principle, all the aforesaid Church Fathers are convinced that man, as promised in the sixth Beatitude, can be granted the grace of seeing God. Yet, he will not see him face to face. The Fathers agree that since man is created in the image and likeness of God, one can see his reflection in the human heart. Describing the meaning of "heart" they refer to the biblical approach, according to which it is a place of spiritual life, where one makes decisions and conducts dialogue with God. In order for the heart to become pure, it must be purified from all faults and sins. This is done primarily by keeping God's commandments and also by developing all kinds of virtues. Only purified hearts, not only free from sin but full of faith and love, can see God. This vision should be understood as a mystical experience. Saint Augustine emphasises that it means seeing God in the act of contemplation.

\section{Bibliography}

\section{Sources}

Anonymous, Opus imperfectum in Matthaeum IX (PG 56, 679-684); trans.: Anonymous, "Incomplete Work on Matthew, Homily 9," Matthew 1-13 (ed. M. Simonetti) (Ancient Christian Commentary on Scripture, New Testament 1a; Dovners Grove, IL: IVP Academic 2001) 94.

Appolinarius Laodicenus, "Fragmenta in Matthaeum 13,1-13," Matthaus-Kommentare aus der griechischen Kirche (ed. J. Reuss) (Texte und Untersuchungen zur Geschichte der altchristlichen Literatur 61; Berlin: Akademie-Verlag 1957) 5; trans.: Apollinaris of Laodicea, "Fragments on Matthew 13," Matthew 1-13 (ed. M. Simonetti) (Ancient Christian Commentary on Scripture. New Testament 1a; Dovners Grove, IL: IVP Academic 2001) 94.

Augustinus Hipponensis, De sermone Domini in monte (PL 34, 1229-1308).

Augustinus Hipponensis, De Trinitate (PL 42, 819-1098).

Augustinus Hipponensis, De Genesis ad litteram imperfectus liber (PL 34, 220-246).

Augustinus Hipponensis, Enarrationes in Psalmos (Corpus Christianorum. Series Latina 38/1-2; Turnhout: Brepols 2013); trans. M. Boulding: Augustine of Hippo, Expositions of the Psalms 51-72 (The Works of Saint Augustine. A Translation for the $21^{\text {st }}$ Century 3/17; Hyde Park, NY: New City Press 2001).

Augustinus Hipponensis, "Sermo 53, 6," Miscellanea Agostiniana (ed. A. Casamassa) (Roma 1930) I, 633; trans: Augustine of Hippo, "Sermon 53, 6," Matthew 1-13 (ed. M. Simonetti) (Ancient Christian Commentary on Scripture. New Testament 1a; Dovners Grove, IL: IVP Academic 2001) 93.

Chromatius Aquileiensis, "Tractatus LXI in evangelium Matthaei," Chromatii Aquileiensis opera (eds. R. Etaix - J. Lemarié) (Corpus Christianorum. Series Latina 9A; Turnholti: Brepols 1974) 185-498; trans: Chromatius of Aquileia, "Tractate on Matthew," Matthew 1-13 (ed. M. Simonetti) (Ancient Christian Commentary on Scripture. New Testament 1a; Dovners Grove, IL: IVP Academic 2001) 93.

Clemens Alexandrinus, Stromata (PG 8, 685-1382; PG 9, 9-602). 


\section{PAWE WYGRALAK}

Gregorius Nyssenus, Orationes VIII de beatitudinibus," Gregorius Nyssenus, De oratione dominica. De beatitudinibus (ed. J. F. Callahan) (Gregorii Nisseni Opera 7/2, Leiden: Brill 1992) 77-169; trans. S.G. Hall: Gregory of Nyssa, "Homilies on the Beatitudes," Gregory of Nyssa: Homilies on the Beatitudes. an English version with commentary and supporting studies. Proceedings of the Eight International Colloquium on Gregory of Nyssa (Paderborn, 14-18 September 1998) (eds. H.R. Drobner - A. Viciano) (Vigiliae Christianae Supplements 52; Leiden - Boston - Köln: Brill 2000) 23-90.

Hieronymus, Commentarii in evangelium Matthaei (ed. E. Bonnard) (Sources chrétiennes 242; Paris: Cerf 1977); trans. T.P. Scheck: St. Jerome, Commentary on Matthew (The Fathers of the Church 117; Washington, D.C.: Catholic University of America Press 2008).

Hilarius Pictaviensis, Commentarius in Matthaeum (ed. J. Doignon) (Sources chrétiennes 254; Paris: Cerf 1978); trans. D.H. Williams: Hilary of Poitiers, Commentary on Matthew (The Fathers of the Church 125; Washington D.C.: Catholic University of America Press 2012).

Johannes Chrysostomus, In Matthaeum homiliae (PG 57-58).

Leo Magnus, Sermones (PL 54, 141-468); trans. J.P. Freeland - A. J.Conway: St. Leo the Great, Sermons (The Fathers of the Church 93; Washington D.C.: Catholic University of America Press 1996).

\section{References}

Czyżewski, B., “Błogosławieni, którzy wprowadzają pokój’ (Mt 5,9) w interpretacji ojców Kościoła," Verbum Vitae 30 (2016) 231-257.

Daniélou, J., "Chronologie des oeuvres de Grégoire de Nysse," Studia Patristica 7 (1966) $159-162$.

Degórski, B., "Le „Beatitudini” nel Commentarium in Matthaeum di san Girolamo," Cuestiones Teológicas 37/88 (2010) 265-280.

Krupa, L.A., Obraz Boży w człowieku według nauki św. Augustyna (Lublin: Towarzystwo Naukowe KUL 1948).

Ladaría, L.F., "Człowiek stworzony na obraz Boga," Człowiek i jego zbawienie (ed. B. Sesboüé) (Historia Dogmatów 2; Kraków: Wydawnictwo “M” 2001) 81-129.

Léon-Dufour, X. (ed.), Słownik teologii biblijnej, 2 ed. (Poznań - Warszawa: Pallottinum 1982). Mateo-Seco, L.F., “Obrazy Obrazu (Rodzaju 1, 26 i Kolosan 1, 15 u św. Grzegorza z Nyssy),” Vox Patrum 49 (2006) 367-381.

Mazanka, P., "Refleksje o rozumieniu czystości serca w filozofii i teologii," Fides et Ratio 4 (2014) 73-92.

Muszyński, H.J., Błogosławieni Pana. Rozważania na temat błogosławieństw w Kazaniu na Górze (Gniezno: Gaudentinum 1996).

Nautin, P., "L'Opus imperfectum in Matthaeum et les Ariens de Constantinople," Revue d'Histoire ecclesiastique 67 (1972) 381-408, 745-766.

Przyszychowska, M., "Wstęp," Grzegorz z Nyssy, Homilie do błogosławieństw (Źródła Myśli Teologicznej 34; Kraków 2005) 5-24.

Simonetti, M., "Note sull'Opus imperfectum in Matthaeum," Studi Medievali (third series) 10 (1969) 117-200.

Špidlík, T. - Gargano, I., "Duchowość Ojców greckich i wschodnich," Duchowość Ojców Kościoła (Kraków: Homo Dei 2004) 7-178. 
Tyburowski, K., "Człowiek jako obraz i podobieństwo Boga w myśli św. Grzegorza z Nyssy," Studia Sandomierskie 14/2 (2007) 313-320.

Uthemann, K.H., "Gregor von Nyssa, De beatitudinibus, Oratio VI: 'Selig, die reinen Herzens sind. Denn sie werden Gott schauen' (Mt 5,8)," Gregory of Nyssa: Homilies on the Beatitudes: an English version with commentary and supporting studies. Proceedings of the Eight International Colloquium on Gregory of Nyssa (Paderborn, 14-18 September 1998) (eds. H.R. Drobner - A. Viciano) (Leiden - Boston - Köln: Brill 2000) 185-227. 
